\title{
PEMBERDAYAAN SDM KELOMPOK TANI DALAM PENGOLAHAN KEONG MAS MENJADI PAKAN TERNAK
}

\author{
Syamsir \\ Jurusan Administrasi Publik, Fakultas Ilmu Sosial, Universitas Negeri Padang \\ Email: syamsir@ fis.unp.ac.id \\ Karjuni Dt. Maani \\ Jurusan Administrasi Publik, Fakultas Ilmu Sosial, Universitas Negeri Padang \\ Email: dtmaani@yahoo.com

\section{Jumiati} \\ Jurusan Administrasi Publik, Fakultas Ilmu Sosial, Universitas Negeri Padang \\ Email: upikjumiati@yahoo.com
}

\begin{abstract}
This article (study) was summarized based on writer experiences in conducting Community Service program among farmer group organizations in Anduriang Village at Padang Pariaman Regency. This program was intended to increase the understanding and awareness of farmer groups about the benefits of golden snails, which so far have only been seen as crop pests for farmers, and then made them a source of income. This study was inspired by various conditions that indicated the powerless of the farmer groups in overcoming the problem of golden snail pests in the Anduriang Village at Padang Pariaman Regency. This issue was reflected in part from the lack of understanding and awareness of farmers in controlling the golden snail pests. Based on this condition, various farmer empowerment policies and programs were needed to be implemented in the form of increasing the capacity of the parmers in economic development of the society, especially for the farmer group organization as target groups in this program. These empowerment activities and programs needed to be conducted collaboratively and synergistically between the local government and universities.
\end{abstract}

Keywords: Empowerment, keong mas, pakan ternak, economic development

How to Cite: Syamsir, Karjuni Dt. Maani dan Jumiati. 2019. Pemberdayaan SDM Kelompok Tani Dalam Pengolahan Keong Mas Menjadi Pakan Ternak. 3(2): pp. 178-189. DOI: https://doi.org/10.24036/jess/vol3-iss2

\section{Pendahuluan}

Pemberlakuan otonomi daerah di Indonesia yang telah berlangsung selama hampir tiga dasawarsa memang telah membawa banyak perubahan ke arah kemajuan di berbagai daerah. Namun bila dicermati secara lebih seksama ternyata masih ada kelompok-kelompok masyarakat di daerah yang belum tersentuh oleh perubahan atau setidaknya agak terlupakan dalam proses pembangunan, terutama masyarakat marjinal petani di desa-desa. Padahal bila dicermati pula, mereka sangat potensial untuk dikembangkan secara ekonomi melalui sumber-sumber daya alam yang secara potensial pula ada di sekeliling mereka. Artinya, cukup banyak potensi yang ada di sekitar masyarakat petani yang sebenarnya dapat dimanfaatkan sebagai sumber 
pendapatan masyarakat dan hal ini sangat perlu mendapat perhatian dari pemerintah setempat melalui program-program pemberdayaan.

Pemberdayaan masyarakat seringkali dimaknai sebagai strategi mengembangkan masyarakat dengan memulainya melalui penyadaran, pencerahan, dan pemberdayaan para pelaksana pemberdaya, atau melalui kelompok elite pemimpin rakyat, atau dimulai dengan memberdayakan institusi yang ada di level atas (Cook, Sarah dan Macaulay, 1996). Namun, pemberdayaan dalam pemaknaan seperti ini seringkali menempatkan masyarakat sebagai obyek di dalam pemberdayaan dan hal ini cenderung tidak efektif untuk mewujudkan pembangunan masyarakat (Prasetyono, dkk, 2017). Dalam tulisan ini penulis akan merujuk kepada konsep pemberdayaan yang dikemukakan oleh Andeas dan Savitri (2016) yang menyatakan bahwa pemberdayaan merupakan usaha membangun hubungan kekuatan dan kemampuan individu dengan sistem bantuan yang alami, dan perilaku proaktif menuju kebijakan sosial dan perubahan sosial secara bottup-up.

Pemberdayaan dan pelatihan masyarakat petani melalui berbagai cara dan upaya memang menjadi suatu keharusan, termasuk peningkatan pengetahuan dan pemahaman mereka terhadap pengolahan sumber daya yang ada di sekeliling mereka menjadi produk-produk bernilai ekonomis dalam rangka meningkatkan pendapatan mereka untuk menunjang kehidupan ekonomi sehari-hari. Di kalangan masyarakat Kenagarian Anduring Kabupaten Padang Pariaman misalnya, terdapat potensi keong mas yang selama ini mereka anggap sebagai hama pertanian padi di sawah, yang sebenarnya dapat diolah dan dikembangkan menjadi produk pakan ternak yang sangat bermanfaat dan prospektif dalam pengembangan ekonomi masyarakat petani.

Populasi keong mas yang terdapat di daerah ini sangat banyak, terutama pada saat musim petani turun ke sawah, sekitar bulan Januari - Maret setiap tahunnya. Sangat disayangkan bila potensi ini tidak dimanfaatkan dan dikembangkan oleh para petani sebagai salah satu alternatif untuk mengembangkan ekonomi mereka. Berikut ini adalah beberapa ilustrasi atau gambar yang menunjukkan potensi keong mas yang diambil pada 9 Maret 2018 lalu di Kenagarian Anduring, Padang Pariaman.
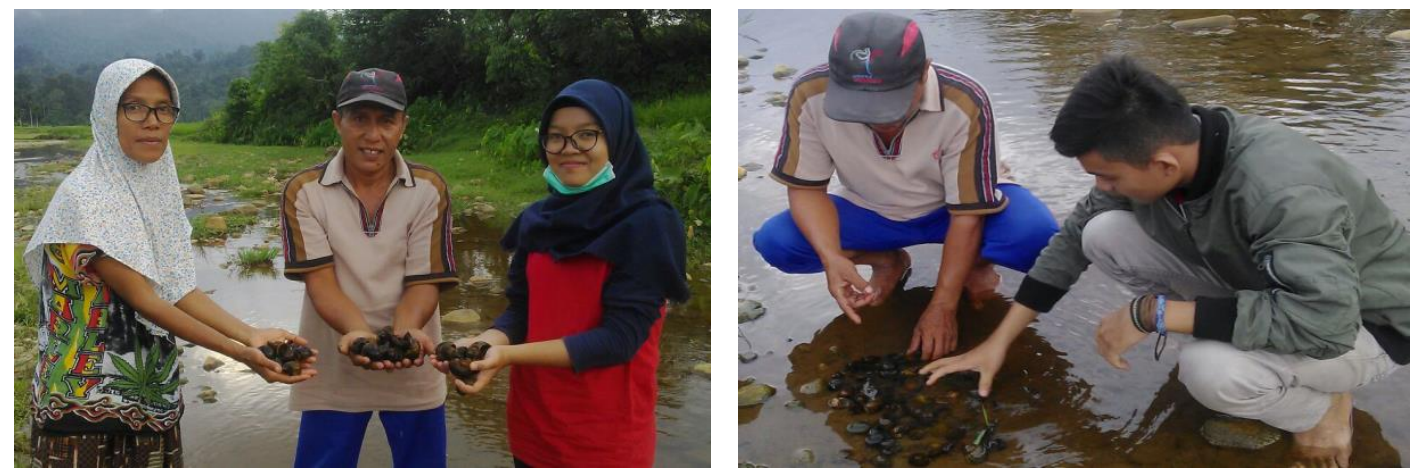

Berdasarkan kondisi, analisis situasi, dan rasional seperti yang dikemukakan di atas, maka diperlukan suatu kegiatan pemberdayaan, pelatihan, dan pendampingan terhadap kelompok mitra, antara lain dalam bentuk peningkatan pengetahuan, pemahaman, dan keterampilan pengolahan keong mas menjadi pakan ternak. Kegiatan ini dilakukan melalui program kegiatan pengabdian masyarakat yang dengan melibatkan sekitar 10 orang anggota dari 2 kelompok tani yang ada di Kenagarian Anduring Kabupaten Padang Pariaman. Melalui mereka ini diharapkan 
akan terjadi diseminasi pegetahuan dan keterampilan terhadap anggota kelompok tani lainnya di daerah ini.

Berdasarkan analisis situasi dan pembenaran yang dilakukan bersama mitra, terlihat bahwa permasalahan yang harus ditangani bersama adalah: 1) Dalam kasus di Kenagarian Anduring Kabupaten Padang Pariaman, masih terdapat indikasi rendahnya kesadaran dan pemahaman masyarakat, terutama kelompok tani terhadap pentingnya pemanfaatan potensi keong mas yang selama ini hanya dipandang sebagai hama tanaman bagi petani dan menjadikannya sebagai sumber pendapatan; 2) Tidak termanfaatkannya potensi keong mas sebagai sumber ekonomi juga disebabkan oleh kurangnya pengetahuan dan keterampilan masyarakat, terutama kelompok tani dalam mengolah dan mengelola keong mas menjadi produk yang bernilai ekonomis, terutama bahan pakan ternak; 3) Di sisi lain, Pemerintah Kabupaten Padang Pariaman, melalui Dinas Pertanian dan Peternakan, sejauh ini belum begitu efektif dalam pemberdayaan masyarakat petani di Kenagarian Anduring, terutama dalam pemanfaatan sumber daya keong mas yang cukup potensial dikembangkan menjadi produk-produk bernilai ekonomis bagi masyarakat petani.

\section{Tinjauan Kepustakaan}

Keong mas merupakan sumber protein hewani alternatif untuk ternak. Rumah atau cangkangnya bisa digunakan sebagai sumber mineral. Walaupun tidak sebaik kualitas tepung ikan, daging keong mas bisa digunakan sebagai sumber protein Tarigan, (2008). Masalah utama penggunaan keong mas adalah adanya racun pada lendirnya, tetapi tidak terlalu berbahaya untuk ternak. Namun demikian, metode pengolahan yang baik akan dapat menghilangkan racun tersebut.

Namun demikian, daging keong mas, selama ini masih belum banyak mendapat perhatian oleh masyarakat, bahkan mereka cenderung masih mengabaikannya. Mereka secara umum lebih memandang keong mas sebagai hama tanaman padi di sawah karena hewan ini mampu merusak tanaman padi dengan tingkat kerusakan yang parah. Kondisi ini membuat negatifnya respons atau tanggapan masyarakat terhadap spesies keong mas ini.

Pemanfaatan keong mas sebagai pakan ternak sebenarnya dapat merupakan salah satu solusi untuk mendapatkan pakan ternak alternatif dan berkualitas untuk mendorong peningkatan produksi usaha ternak. Daging keong dapat diberikan untuk pakan ternak dalam keadaan mentah (segar) maupun dalam bentuk olahan. Biasanya keong mas dijadikan pakan pada jenis ternak seperti sapi, kambing, unggas (ayam, itik). Pada pengembangan ternak itik, keong mas merupakan pakan campuran sebagai sumber protein yang murah. Selain mengandung banyak protein, keong mas juga kaya akan kalsium. Penggunaan keong mas sebagai pakan itik sebagai sumber protein hewani telah dilakukan sejak lama, setidaknya sejak tahun 1985 Kompiang dkk (1994).

Keong mas memang sangat sulit untuk dibasmi secara tuntas. Penyebarannya cukup luas \& banyak merusak pertanaman padi, kerusakan yang ditimbulkannya bisa mencapai intensitas 13,2 - 96,5 \% Pitojo, (1996). Bahkan menurut Budiyono (2006) keong mas pernah menyebabkan kerusakan hingga 10-40\% dari keseluruhan areal pertanaman padi di Indonesia yakni di Jawa, Sumatra, Kalimantan, NTB, dan Bali. Akan tetapi bila potensi keong mas ini dapat dikelola dengan baik, maka ia 
bisa menjadi sumber pendapatan atau ekonomi yang cukup menjanjikan, termasuk di Kenagarian Anduring Kabupaten Padang Pariaman ini.

Namun dalam kenyataannya pemerintah daerah setempat belum mampu secara efektif memanfaatkan dan memberdayakan potensi ekonomi ini secara serius. Titik lemah pemanfaatan potensi keong mas di daerah ini antara lain terletap pada pengetahuan dan keterampilan masyarakat yang kurang dalam mengolah keong mas menjadi produk ekonomi seperti pakan ternak, disamping ketiadaan modal untuk mengolah potensi keong mas tersebut, terutama mesin pengolah (penggiling) dan sarana/prasarana lainnya yang dibutuhkan untuk proses pengolahan tersebut.

Fenomena ini tidak boleh dibiarkan berlarut-larut. Terlebih dengan semakin tingginya tuntutan kehidupan ekonomi dan persaingan global saat ini. Untuk itu perlu pembenahan yang terencana dan terprogram mengenai pola pikir pemerintah dan masyarakat petani tentang pentingnya pemberdayaan dan pelatihan pemanfaatan sumber daya keong mas manjadi produk pakan ternak bagi masyarakat petani di Kenagarian Anduring Kabupaten Padang Pariaman. Pembenahan yang terencana dan terprogram ini akan dilakukan melalui pemberdayaan kelompok tani yang pada hakekatnya adalah upaya merevitalisasi dan membantu pelaksanaan fungsi pemerintahan nagari sehingga berkontribusi maksimal terhadap pembangunan di Kenagarian Anduring Kabupaten Padang Pariaman.

Rencana program kegiatan pengabdian masyarakat ini bertolak dari berbagai kondisi yang mengidikasikan kurangnya kesadaran, pengetahuan, dan pemahaman masyarakat kelompok tani di Kenagarian Anduring Kabupaten Padang Pariaman dalam pemanfaatan potensi keong mas sebagai produk bernilai ekonomis bagi masyarakat petani di daerah yang bersangkutan. Mereka selama ini hanya memandang keong mas lebih sebagai hama tanaman padi sawah ketimbang sebagai potensi ekonomis yang bisa dikembangkan menjadi sumber pendapatan bagi para petani.

Selain kesadaran, pengetahuan, dan pemahaman yang kurang dalam pemanfaatan potensi yang ada, permasalahan lain yang dihadapi oleh masyarakat petani adalah persoalan sarana dan prasarana serta modal pengembangan usaha yang sangat kurang, seperti mesin pengolah yang tidak ada, disamping teknik pemasaran produk yang tidak mereka pahami. Pembinaan dari tenaga ahli yang terkait dengan permasalahan yang mereka hadapi juga hampir tidak ada. Perhatian dari pihak pemerintah daerah juga mereka rasakan sangat kurang, sehingga mereka akhirnya menerima saja apa adanya persoalan yang ada.

\section{Metode Penelitian}

Penelitian ini merupakan penelitian survey dengan menggunakan pendekatan kualitatif. Objek penelitian ini adalah para petani, terutama mereka yang tergabung dalam kelompok tani (poktan) Damai Sejahtera dan Cahaya Bunda, di Kenagarian Anduriang Kabupaten Padang Pariaman. Informasi atau data dalam penelitian ini diperoleh dari para informan penelitian, yang terdiri dari para Walinagari Anduriang, Wali Jorong, beberapa pejabat Dinas Pertanian dan Tanaman Pangan dan Dinas Koperasi Tenaga Kerja dan UKM, Kabupaten Padang Pariaman, Penyuluh Pertanian di Kenagarin Anduriang, dan Pengurus Kelompok Tani Damai Sejahtera dan Cahaya Bunda beserta anggotanya. Penelitian ini diadakan berbarengan dengan program kegiatan pengabdian kepada masyarakat yang telah diadakan selama 5 kali (sesi) pertemuan pada periode Juli-Desember 2019. 
Data primer dalam penelitian ini menyangkut tentang permasalahan yang dihadapi para petani dalam pemanfaatan potensi keong mas sebagai produk bernilai ekonomis bagi masyarakat petani di daerah yang bersangkutan. Data penelitian ini dikumpulkan melalui wawancara mendalam (depth interview) dan observasi. Untuk menguji kredibilitas data digunakan teknik triangulasi melalui strategi pengecekan derajat kepercayaan penemuan hasil penelitian dengan beberapa teknik pengumpulan data (triangulasi metode). Selanjutnya data diolah secara kualitatif dengan model yang digunakan dalam analisis adalah model interaktif seperti yang digambarkan oleh Miles dan Huberman sebagai berikut: (1) reduksi data; (2) penyajian data; (3) interpretasi data, dan (4) penarikan kesimpulan.

\section{Hasil Penelitian dan Pembahasan}

\section{Tujuan dan Manfaat Kegiatan}

Tujuan atau atau target yang dapat diharapkan dari pelaksanaan kegiatan pengabdian kepada masyarakat melalui skim Program Pengembangan Nagari Binaan (PPNB) ini, diantaranya:

1. Tumbuhnya kesadaran dan pemahaman kelompok mitra (Poktan Damai Sejahtera dan Poktan Cahaya Bunda) terhadap pentingnya pemanfaatan potensi keong mas yang selama ini hanya dipandang sebagai hama tanaman bagi petani dan menjadikannya sebagai sumber mata pencaharian;

2. Meningkatnya pengetahuan dan keterampilan kelompok mitra dalam mengolah keong mas menjadi produk yang bernilai ekonomis, terutama bahan pakan ternak;

3. Pada akhirnya target kegiatan ini adalah meningkatnya pendapatan masyarakat, terutama kelompok mitra, dalam memenuhi kebutuhan hidup sehari-hari.

Sementara luaran yang diharapkan dari kegiatan PPNB ini adalah:

1. Untuk tahap awal, minimal 50 kilogram pakan ternak berbahan baku keong mas per minggu yang dibuat/diproduksi oleh kelompok mitra dalam program pelatihan/pemberdayaan ini.

2. Hasil kegiatan ini akan diterbitkan atau didiseminasikan melalui jurnal ilmiah nasional ber-ISSN atau melalui prosiding seminar nasional/internasional.

Hasil kegiatan pemberdayaan masyarakat ini akan dievaluasi kembali pada akhir kegiatan untuk mendapatkan kesesuaian dengan tujuan yang telah ditetapkan pada awal kegiatan, selama proses kegiatan pelatihan berlangsung, dan di akhir pelatihan. Pencapaian tujuan diukur melalui penilaian produk (hasil pengolahan keong mas menjadi produk pakan ternak) dan evaluasi kinerja program. Tes performansi digunakan untuk melihat sejauhmana peserta telah memahami dan berhasil menyerap materi yang disajikan dan menerapkannya dalam kegiatan produksi. Tes evaluasi kinerja program digunakan untuk melihat sejauhmana peningkatan keterampilan peserta dalam mengolah dan memasarkan produk pakan ternak berbahan baku keong mas.

Hasil kegiatan pemberdayaan masyarakat ini dievaluasi pada akhir kegiatan untuk mendapatkan kesesuaian dengan tujuan yang telah ditetapkan pada awal kegiatan, selama proses kegiatan pelatihan berlangsung, dan di akhir pelatihan. Pencapaian tujuan diukur melalui penilaian produk (hasil pengolahan keong mas menjadi produk pakan ternak) dan evaluasi kinerja program. Tes performansi digunakan untuk melihat sejauhmana peserta telah memahami dan berhasil menyerap materi yang disajikan dan menerapkannya dalam kegiatan produksi. Tes evaluasi kinerja program digunakan untuk melihat sejauhmana peningkatan 
keterampilan peserta dalam mengolah dan memasarkan produk pakan ternak berbahan baku keong mas.

\section{Masalah yang Dialami Petani dalam Pengendalian Keong Mas}

Di antara beberapa masalah yang masih menggejala di kalangan para petani di Kenagarian Anduriang Kabupoaten Padang Pariaman, terutama petani sawah, pada saat musim turun ke sawah adalah masalah hama keong mas yang sangat banyak populasi atau perkembangannya pada saat musim penduduk (petani) turun ke sawah. Musim ini biasanya berlangsung sekitar bulan Januari - Maret setiap tahunnya (Sumber: wawancara dengan Walikorong Sipisang-Sipinang, Kenagarian Anduring Kabupaten Padang Pariaman, 10 Januari 2018). Masalah ini sebenarnya sudah sejak lama dirasakan dan dialami penduduk sekitar serta dampak negatifnya terhadap produksi padi penduduk tidaklah sedikit. Bila hama keong mas ini tidak dibasmi secara serius, maka bisa jadi petani akan gagal panen karena tanaman padinya habis dirusak oleh hama keong mas yang populasinya sangat banyak itu. Namun entah mengapa sampai saat ini belum juga ditemukan jawaban dan solusi yang tepat sehingga dapat menyelesaikan persoalan rumit dan pelik yang dialami oleh petani tersebut.

Para petani seringkali tidak berdaya mengatasi permasalahan hama keong mas ini. Penyebabnya sangat beraneka ragam, mulai dari ketidaktahuan cara pemberantasan yang tepat sampai pada persoalan biaya yang dibutuhkan dalam upaya pemberantasan hama keong mas tersebut. Namun pada umumnya antara lain disebabkan oleh kurangnya pengetahuan tentang bagaimana cara meberantas hama dengan tepat, bahkan memanfaatkan potensi hama keong mas tersebut menjadi pakan ternak yang sangat banyak manfaatnya bagi perkembangan ternak yang bersangkutan. Menurut beberapa literatur tentang hama keong mas, sebenarnya keong mas sangat berpotensi untuk dikembangkan menjadi pakan ternak, seperti ikan, ayam, dan itik, dan sangat baik dampaknya bagi ternak tersebut.

Kandungan protein yang tinggi dalam daging keong mas dapat digunakan sebagai pakan itik atau belut karena belut merupakan hewan karnivora sehingga membutuhkan pakan dengan kadar protein yang tinggi. Selain banyak mengandung protein, hewan dari keluarga moluska ini juga kaya akan kalsium. Penggunaan keong mas untuk pakan itik terbukti mampu menaikkan hasil telur hingga $80 \%$. Pemberian pakan sekitar 4,5\% tepung keong mas pada sapi potong juga memberikan hasil pertumbuhan yang baik dan tingkat keuntungan paling tinggi dibandingkan pemberian pakan lain. Sebagai pakan ikan, penggantian kandungan tepung ikan menjadi tepung keong mas sebanyak 25 hingga $75 \%$ memberikan pengaruh cukup baik terhadap laju pertumbuhan harian individu, efisiensi pakan, retensi protein, dan retensi lemak (Ruslan dan Harianto, 2009).

Keong mas cukup potensial sebagai sumber protein hewani. Keong mas memiliki kandungan gizi lain yakni kalori dan karbohidrat. Keong mas juga mengandung vitamin dan mineral yang dibutuhkan oleh tubuh. Beberapa mineral yang ditemukan dalam daging keong mas antara lain kalsium, natrium, kalium, fosfor, magnesium, seng, dan zat besi (Budiharjo dalam Sulistiono, 2007; Julfereina, 2008; dan BPPT dalam Sulistiono, 2007). Selain itu, penambahan tepung keong mas pada pakan ayam petelur dapat meningkatkan kualitas pakan dalam peningkatan konsentrasi kuning telur dalam peningkatan kandungan Omega-3 pada telur ayam Ras petelur (Nurmufidah, 2010.) 
Kurangnya pengetahuan dan keterampilan masyarakat petani di Kenagarian ANduriang Kabupaten Padang Pariaman tentang pemanfaatan potensi hama keong mas ini tentu saja menjadi kendala yang besar bagi perkembangan pertanian di kawasan ini, dan pada akhirnya akan berdampak pada penurunan kualitas kehidupan ekonomi para petani. Padahal sebenarnya hama keong mas ini dapat dimanfaatkan secara ekonomis untuk keperluan pakan ternak lainnya. Kondisi ini jelas sangat memprihatinkan di tengah-tengah upaya dan keinginan besar pemerintah daerah untuk meningkatkan kualitas ekonomi masyarakat. Oleh karenanya perlu segera difikirkan sebuah strategi (solusi) yang jitu untuk persoalan ini. Artinya, masyarakat perlu diberdayakan tentang cara mengolah hama keong mas yang selama ini menjadi musuh besar petani menjadi sesuatu yang bernilai ekonomis sangat tinggi bagi masyarakat, terutama masyarakat petani di daerah ini.

Kelompok tani sebagai wadah penyaluran aspirasi para petani dapat difungsikan dalam pemberdayaan masyarakat petani secara keseluruhan. Artinya, Kelompok tani tidak hanya diharapkan sebagai organisasi penerima dana segar dari pemerintah dalam program-program tertentu, tetapi juga diharapkan dapat digunakan sebagai sarana dan wadah akan mampu memacu motivasi para petani lainnya dalam pemanfaatan potensi pertanian bagi kemajuan para petani dalam mengolah lahan pertanian mereka. Secara sederhana model solusi pemberdayaan kelompok tani yang ingin ditawarkan melalui program pengabdian kepada masyarakat skim PPNB (Program Pengembangan Nagari Binaan) ini, khususnya kelompok tani di Kenagarian Anduring, Kabupaten Padang Pariaman ini dapat digambarkan pada bagan berikut.

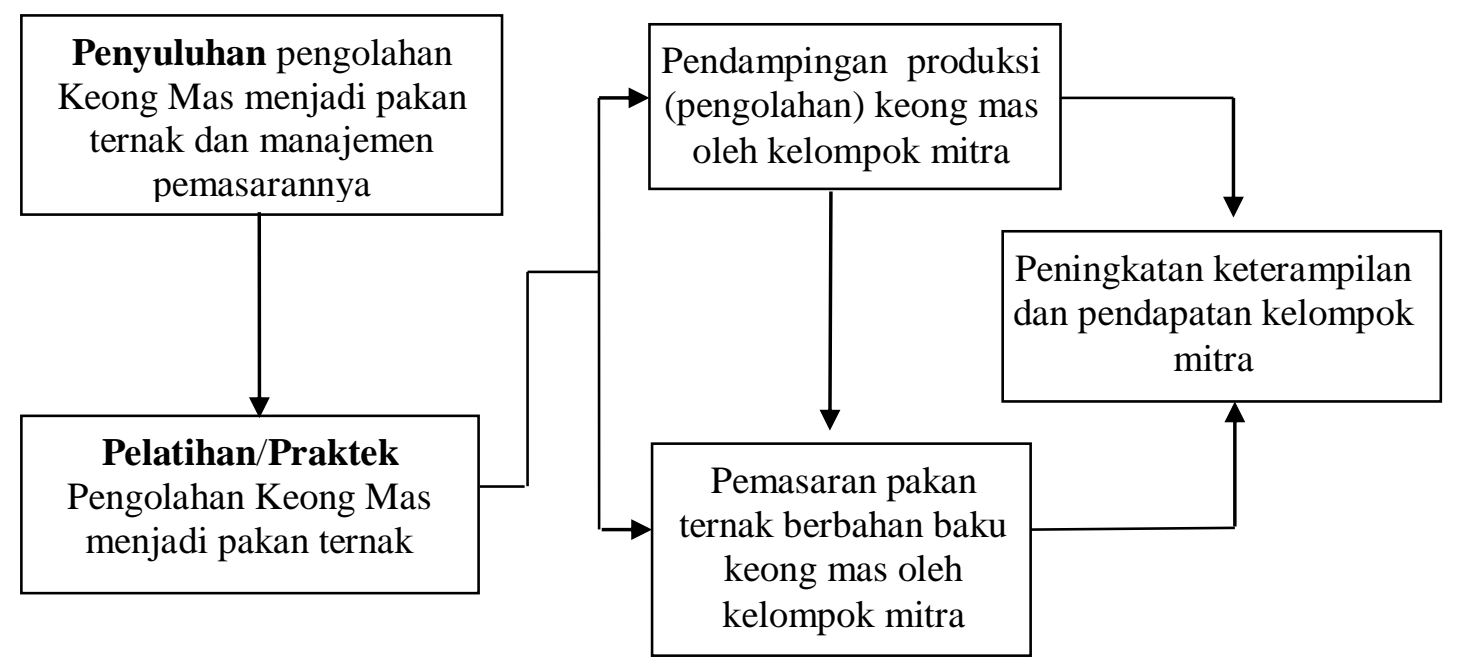

Gambar 1. Model Solusi Pemberdayaan SDM Kelompok Tani Dalam Pengolahan Keong Mas Menjadi Pakan Ternak di Nagari Anduring Padang Pariaman

Berbagai program pemberdayaan dan pelatihan ini telah disiapkan dan diterapkan untuk meningkatkan pemahaman dan keterampilan kelompok mitra, khususnya kelompok tani di Kenagarian Anduring Kabupaten Padang Pariaman, baik secara substansial maupun prosedural (pengetahuan dan keterampilan) agar supaya lahir para kelompok tani profesional yang mampu menjadi pionir dan motivator bagi para petani lainnya dalam pengolahan keong mas yang selama ini menjadi musuh (hama) dalam pertanian menjadi sumber pendapatan bagi kelompok mitra (petani). Dengan 
demikian kualitas kehidupan dan ekonomi masyarakat secara keselurahan juga diharapkan akan meningkat secara bertahap.

\section{Metode Pendekatan yang Ditawarkan}

Untuk mencapai tujuan yang telah ditetapkan, maka metode yang digunakan dalam pemberdayaan dan pelatihan ini adalah "metode penyuluhan partisipatif" didasarkan pada prinsip-prinsip partisipatori yang menekankan kepada asas peran serta seluruh peserta untuk mencapai tujuan dan sasaran yang ditentukan. Tahap penyuluhan ini dimulai dengan penetapan tujuan kegiatan penyuluhan, kemudian diikuti dengan pengisian materi penyuluhan/pelatihan sehingga memberikan hasil yang diharapkan. Disamping itu ada beberapa teknik yang digunakan dalam kegiatan ini, yaitu: 1) diskusi pendahuluan, 2) praktek dan peragaan, 4) brainstorming, 5) ceramah, dan 6) diskusi, dan 7) pendampingan

1. Diskusi Pendahuluan mengenai fenomena yang terjadi lapangan menyangkut kondisi potensi keong mas yang ada di lingkungan kehidupan petani, masalah dan kemunginan solusinya menurut pendapat mereka. Teknik ini dilakukan untuk memancing partisipasi dalam mengemukakan persoalan yang mereka hadapi di lapangan dan membangun suasana agar selalu segar dalam pelatihan, mengatasi kejenuhan dan menumbuhkan kesadaran baru dan pemahaman terhadap kondisi riil para petani di lapangan.

2. Brainstorming; merupakan proses pengumpulan gagasan bersama-sama dan menjadikan suatu inventarisasi terhadap gagasan yang dikemukakan. Brainstorming dilaksanakan untuk materi peningkatan pemahaman dalam upaya peningkatan dan penyegaran pemahaman kelompok petani terhadap persoalan yang mereka hadapi dan kemungkinan solusinya.

3. Ceramah; dilakukan untuk memberikan materi yang sifatnya normatif menyangkut pengolahan potensi keong mas menjadi produk-produk ekonomis di kalangan para petani.

4. Diskusi; merupakan proses yang dilakukan untuk membahas masalah yang dihadapi dan dilakukan pada sebagian besar materi yang disajikan.

5. Praktek dan peragaan, uji coba dan peragaan, terutama menyangkut cara atau teknik pengolahan potensi keong mas menjadi produk-produk ekonomis terutama pakan ternak

6. Pendampingan; dilakukan pada saat pelatihan dan secara berkala setelah pelatihan dalam rangka memaksimalkan hasil pemberdayaan, penyuluhan, dan pelatihan. Pendampingan dalam kegiatan ini telah dilakukan sebanyak 4 kali kegiatan, yang mencakupi kegiatan ceramah dan diskusi, praktek pengolahan merebus dan menjemur keong mas, dan praktek penggilingan keong mas menjadi tepung keong mas.

\section{Pelaksanaan, Partisipasi Mitra, dan Evaluasi Pelaksanaan Program}

Program kegiatan pengabdian skim PPNB ini dilaksanakan dalam bentuk pembinaan (terdiri dari penyuluhan, pelatihan, dan praktikum) pengolahan keong mas, yang selama ini menjadi hama petani, menjadi pakan ternak, terutama pakan ayam, itik, dan ikan. Sasaran kegiatan ini adalah para petani yang tergabung dalam 2 kelompok Tani, yaitu Poktan Damai Sejahtera dan Poktan Cahaya Bunda. Kegiatan utama pengabdian 
ini telah dilaksanakan sebanyak 4 kali dari 4 kali yang direncanakan secara berkala. Kegiatan ini dilaksanakan di aula Korong Sipisang-Sipinang kenagarian Anduring, kabupaten Padang Pariaman.
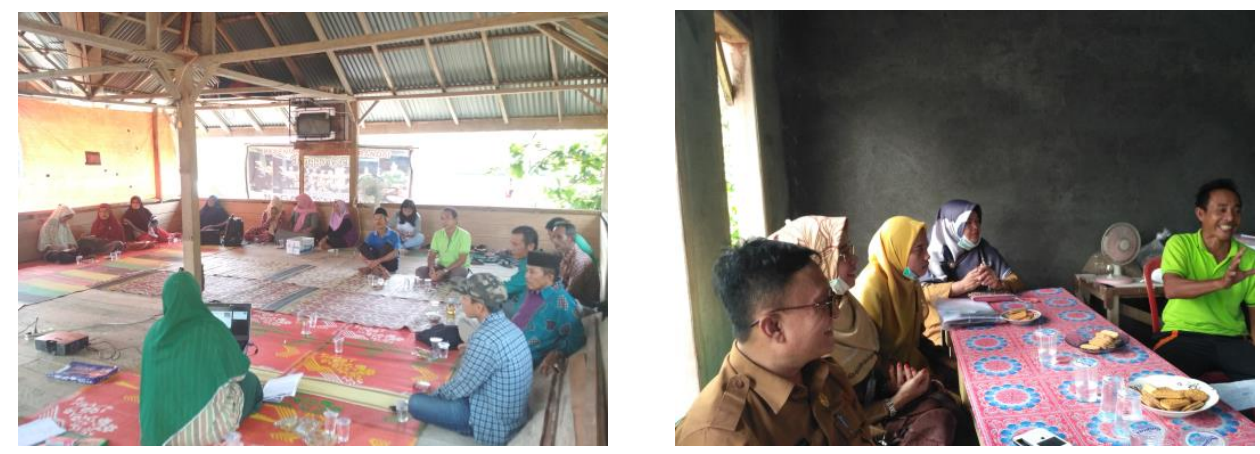

Gambar 2: Penyuluhan oleh pejabat Dinas Pertanian dan Tanaman Pangan Kabupaten Padang

Pariaman dan Dinas Koperasi, Tenaga Kerja, dan UKM Kabupaten Padang Pariaman.

Kegiatan 1 lebih banyak terfokus pada penyuluhan dan pelatihan cara mengolah keong mas menjadi pakan ternak. Sementara kegiatan 2 dan 3 sudah terfokus pada praktikum pengolahan keong mas menjadi bahan setengah jadi dan bahan jadi. Sementara kegiatan 4 lebih diarahkan pada upaya pemasaran bahan yang telah diolah. Sedangkan kegiatan 5 adalah kegitan monitoring dan evaluasi (monev) untuk memantau perkembangan dan kebermanfaatan program kegiatan yang telah dilakukan. Kegiatan praktikum dalam kegiatan ini dilakukan dalam rangka menindaklanjuti pemahaman materi penyuluhan dan pelatihan yang telah diberikan sebelumnya, terutama cara (teknik) pengolahan keong mas menjadi bahan pakan ternak. Kegiatan seperti ini juga dimaksudkan sebagai alat ukur atau indikator dalam penentuan keberhasilan kegiatan ini.

Dalam pelaksanaan kegiatan ini tim pengabdian UNP bekerjasama dengan Pemerintahan Kenagarian Anduriang, Dinas Pertanian dan Tanaman Pangan, dan Dinas Koperasi, Tenaga Kerja, dan UKM Kabupaten Padang Pariaman. Produk keong mas yang telah diolah akhirnya diuji pada laboratorium Jurusan Kimia FMIPA UNP. Hasil uji laboratorium tersebut menggambarkan kandungan dari hasil olahan keong sebagai berikut:

Tabel 1. Hasil Laboratorium Produk Keong Mas Kenagarian Anduriang Kabupaten Padang Pariaman

\begin{tabular}{llcccc}
\hline \multirow{2}{*}{ No. } & Parameter & \multicolumn{3}{c}{ Parameter } & Metode \\
\cline { 3 - 5 } & Daging & Cangkang & $\begin{array}{c}\text { Daging }+ \\
\text { Cangkang }\end{array}$ & \\
\hline 1. & Calcium \% & 55,527 & 93,451 & 80,361 & XRF \\
\hline 2. & Fosfor $(\%)$ & 5,019 & 0,471 & 1,936 & XRF \\
\hline 3. & Zat besi $(\%)$ & 5,587 & 0,724 & 2,274 & XRF \\
\hline 4. & Protein $(\mathrm{gr} / 100$ gr sampel) & 11,71 & 0,30 & 19,98 & XRF \\
\hline
\end{tabular}

Seri terakhir dari kegiatan pengabdian ini adalah kegiatan monitoring dan evaluasi, sekaligus membuktikan apakah hasil kegiatan yang telah dilaksanakan 4 kali sebelumnya telah dipahami dan ditindaklanjuti oleh peserta kegiatan pengabdian. Dari hasil monitoring dan evaluasi, ternyata para peserta telah berhasil memahami 
dan menindaklanjuti kegiatan pelatihan sebelumnya. Hal ini antara lain terlihat dari antusias peserta dalam melajutkan produksi keong mas dan membentuk kelompok produksi baru yang akan mengelola produksi keong mas ini secara lebih professional. Kelompok baru tersebut diberi nama KUAD MAS (Kelompok Usaha Aspirasi Daerah Masyarakat Anduriang Sipisang). Kelompok ini bertekad akan menindaklanjuti kegiatan produksi keong mas ini secara lebih serius dan profesional.

Meskipun kegiatan seri terakhir ini dimaksudkan untuk melakukan monitoring dan evaluasi, namun acara seri terakhir ini juga berkembang ke arah pembimbingan atau kemungkinan penyaluran pemasaran produk keong mas ke beberapa produsen pakan ternak yang memerlukan bahan setengah jadi untuk kebutuhan produksi pakan ternak. Pada kegiatan ini juga disepakati bahwa Tim Pengabdi akan dijadikan sebagai tim perantara antara kelompok tani dengan produsen pakan ternak.

Partisipasi mitra dalam pelaksanaan program PPNB ini adalah sebagai khalayak sasaran yang terlibat langsung dalam pemberdayaan dan pelatihan. Institusi atau pihak yang terlibat langsung dalam pelaksanaan program ini adalah 10 orang anggota kelompok tani yang berasal dari 2 kelompok tani di daerah sasaran dan terbagi ke dalam 2 kelompok sasaran. Kesepuluh anggota peserta ini telah diseleksi dari kelompok tani yang ada dan diperkirakan sangat potensial untuk dilatih dan menjadi pionir serta motivator bagi teman-teman/kolega kelompok tani lainnya di Kebagarian Anduring Kabupaten Padang Pariaman. Selain kelompok tani, pemerintahan nagari juga dilibatkan dalam kegiatan ini terutama terutama kepala Korong Sipisang-Sipinang, Kenagarian Anduriang. Disamping itu, institusi mitra dan pihak pemerintahan nigari juga berperan langsung terhadap operasional kegiatan di lapangan sebagai penyedia fasilitas ruangan dan berbagai kelengkapan teknis lainnya.

Dari hasil evaluasi yang dilakukan terhadap pelaksanaan kegiatan ini melalui observasi dan wawancara dengan sebagian peserta dapat disimpulkan bahwa hasil kegiatan penyuluhan, pelatihan, dan praktikum PPNB pengolahan keong mas menjadi pakan ternak di Kenagarian Andurian Kabupaten Padang Pariaman ini sangat bermanfaat bagi para peserta, terutama para kelompok tani Damai Sejahtera dan Cahaya Bunda di Kenagarian Anduriang Kabupaten Padang Pariaman ini. Hal ini antara lain dibuktikan dari hasil wawancara dan observasi tentang kepuasan mereka mengikuti kegiatan ini, baik kegiatan penyuluhan, pelatihan maupun kegiatan praktikum yang mereka lakukan setelah menerima materi dan pelatihan atau praktikum.

Para peserta dalam kegiatan ini berharapan agar kegiatan ini tidak hanya sampai di sini saja, tapi diteruskan secara periodik di masa yang akan datang dalam bentuk kontrol dan bimbingan melalui kegiatan pengabdian masyarakat lainnya. Bahkan dari pengakuan tim Penyuluh Dinas Pertanian dan Tanaman Pangan mereka sangat mendukung kegiatan-kegiatan seperti ini dan sangat ingin bekerjasama dalam membina kelompok tani di daerah ini. Mereka juga akan berusaha mengusulkan anggaran dana ke Dinas Pertanian dan Tanaman Pangan Kabupaten Padang Pariaman untuk kegiatan-kegiatan sejenis di masa yang akan datang. Mereka beralasan karena kegiatan-kegiatan seperti ini sangat penting dan bermanfaat bagi kelompok tani dan Dinas-dinas terkait di Kabupaten Padang Pariaman. Kegiatan penyuluhan, pelatihan, dan praktikum ini mudah-mudahan akan memancing 
semangat para anggota kelompok tani lainnya untuk berpacu dalam pengembangan ekonomi melalui kegiatan-kegiatan pembinaan kelompok tani.

\section{Penutup}

Berdasarkan uraian dan pembahasan dalam laporan kegiatan pengabdian kepada masyarakat seperti yang telah disampaikan sebelumnya maka dapat disimpulkan bahwa:

1. Pemberdayaan masyarakat marjinal kelompok tani di Indonesia dan Sumatera Barat pada umumnya dan di Kenagarian Anduring Kabupaten Padang Pariaman pada khususnya masih merupakan program yang seharusnya mendapat perhatian dari berbagai pihak, terutama pemerintah dan perguruan tinggi, termasuk dalam pemberdayaan bidang ekonomi dengan memanfaatkan segala potensi yang ada dan yang mungkin dikembangkan;

2. Kegiatan pengabdian skim PPNB UNP TA 2019 tentang Pemberdayaan SDM Kelompok Tani Dalam Pengolahan Keong Mas Menjadi Pakan Ternak di Kenagarian Anduring Padang Pariaman yang dalam realisasinya berbentuk penyuluhan, pelatihan, dan praktikum, telah dapat memenuhi sebagian kebutuhan para kelompok tani terhadap penguasaan keterampilan pengolahan keong mas menjadi bahan pakan ternak dan sekaligus juga dalam rangka pembasmian hama pertanian di kenagarian Anduriang Kabupaten Padang Pariaman dan sekitarnya, terutama di Korong Sipisang-Sipinang,

3. Metode kegiatan yang didahului dengan studi kasus, brainstorming, diskusi, dan ceramah lalu diakhiri dengan pelatihan dapat membantu peserta dalam memahami persoalan yang dihadapi di lapangan, terutama yang berkaitan dengan keterampilan SDM kelompok tani dalam pengolahan keong mas menjadi pakan ternak di kenagarian Anduring Padang Pariaman.

4. Berdasarkan pelatihan yang dilakukan dapat pula disimpulkan bahwa ternyata program pengabdian PPNB tentang pemberdayaan SDM kelompok tani dalam pengolahan keong mas menjadi pakan ternak di kenagarian Anduring Padang Pariaman yang dalam realisasinya berbentuk penyuluhan, pelatihan, dan praktikum ini cukup efektif dalam memberikan peningkatan keterampilan para kelompok tani dalam pengolahan keong mas, yang selama ini dianggap sebagai hama, menjadi bahan pakan ternak yang sangat bermanfaat bagi para petani (terutama anggota kelompok tani) dalam peningkatan perekonomian mereka.

Dalam pelaksanaan kegiatan pengabdian kepada masyarakat di masa-masa yang akan datang, ada beberapa hal yang perlu dilakukan:

1. Program kegiatan PPNB tentang pemberdayaan SDM kelompok tani dalam pengolahan keong mas menjadi pakan ternak ini perlu diadakan secara periodik, berkelanjutan, dan lebih terprogram, terutama pada daerah-daerah dan bagi kelompok tani yang mengalami persoalan yang sama, di tempat yang berbeda.

2. Pelibatan pihak-pihak pendamping dari instansi yang relevan sebagai pemateri perlu dilakukan secara lebih intensif, seperti pendamping dari Dinas Pertanian dan Tanaman Pangan, Dinas Koperasi, Tenaga Kerja, dan UKM, disamping tim pengabdian sendiri. Hal ini sangat baik dilakukan agar sasaran dan tujuan kegiatan pengabdian dapat dicapai secara lebih efektif dan pembinaan keterampilan serta kemampuan para kelompok tani dapat dilakukan secara sinergis antar pihak terkait. 


\section{DAFTAR KEPUSTAKAAN}

Cook, Sarah dan Steve Macaulay. 1996. Perfect Empowerment. Jakarta: PT. Alex Media Computindo.

Prasetyono, Dwi Wahyu, Sri Juni Woro Astuti, Supriyono, dan Ramon Syahrial. 2017. Pemberdayaan Petani Berbasis Modal Sosial dan Kelembagaan. Asian Journal of Innovation and Entrepreneurship. Vol. 02. No. 3. September 2017.

Andeas dan Enni Savitri. 2016. Peran Pemberdayaan Ekonomi Masyarakat Pesisir dan Modal Sosial. Pekanbaru.

Tarigan, S.J.B.R. 2008. "Pemanfaatan Tepung Keong Mas sebagai Substitusi Tepung Ikan dalam Ransum Terhadap Peformans Kelinci Jantan Lepas Sapih”. Skripsi. Universitas Sumatera Utara. Medan.

Kompiang, I.P., J. Dharma, T. Purwadaria, A. Sinurat, dan Supriyati. 1994. "Protein enrichment: Study cassava enrichmen melalui bioproses biologi untuk ternak monogastrik". Kumpulan Hasil-Hasil Penelitian APBN Tahun Anggaran 1993/1994. Bogor: Balai Penelitian Ternak Ciawi Bogor.

Pitojo, S. 1996. Petunjuk Pengendalian dan Pemantauan Keong Mas. Jakarta: Trubus Agriwidya.

Budiyono S. 2006. “Teknik Mengendalikan Keong Mas Pada Tanaman Padi”. Jurnal Ilmu-Ilmu Pertanian 2(2): 128-133.

Ruslan dan Harianto.2009. Penanggulangan Hama Keong Mas.Yogyakarta: PT. Citra Aji Parama.

Sulistiono. 2007. "Pengelolaan Keong Mas (Pomacea Canaliculata). Prosiding. Konferensi Sains Kelautan dan Perikanan Indonesia I. Kampus FPIK, IPB Dramaga, 17-18 Juli 2007.

Julfereina, S., B.R. Tarigan. 2008. Pemanfaatan Tepung Keong Mas sebagai Substitusi Tepung Ikan Dalam Ransum Terhadap Performans Kelinci Jantan Lepas Sapih. Medan: Fakultas Pertanian USU.

Nurmufidah. 2010. "Penambahan Keong Mas Pomacea Canaliculata L Pada Ransum Ayam Petelur Dalam Peningkatan Kandungan Omega 3 Pada Telur". Laporan Penelitian Skripsi. Jurusan Biologi, Fakultas Matematika dan Ilmu Pengetahuan Alam, Universitas Hasanuddin, Makassar. 